\title{
STEPS OF SUSTAINABLE DEVELOPMENT IMPLEMENTATION INTO ENTERPRISE ACTIVITIES
}

\author{
Janusz GRABARA ${ }^{1}$, Paula BAJDOR ${ }^{2}$, Liviu MIHAESCU ${ }^{3}$ \\ ${ }^{1}$ Czestochowa University of Technology, Poland, janusz@ grabara.eu \\ ${ }^{2}$ Czestochowa University of Technology, Poland, paula.bajdor@gmail.com \\ ${ }^{3}$ Lucian Blaga University of Sibiu, Romania, liviu.mihaescu@ulbsibiu.ro
}

\begin{abstract}
Nowadays, principles of the sustainable development concept are present in almost all areas of life, play a key role in efforts to protect the environment, activities for the community and economic development. One of the "beneficiaries" of this concept are the enterprises, both small local as well as those with a global reach. In almost every operating company, in a greater or lesser extent, pillars of sustainable development are used, but before this happened - these companies have to go through a few steps, that led to the full implementation of the sustainable development concept and its application in practical terms. This article presents and describes in detail, the various stages of completion of which is the existence and the practical use of the sustainable development concept in its activities.
\end{abstract}

KEY WORDS: sustainable development, enterprise, implementation, activity, steps

\section{INTRODUCTION}

Orientation of companies to the concept of sustainable development, helping them to increase their market share and gain competitive advantage. Companies implementing the concept of sustainable development are positively received by the market participants and employees, improving morale and employee loyalty, which also contributes to better efficiency and productivity same company (Table 1).

Table 3. Basic targets and benefit characteristics for every dimension of the sustainable development conception

\begin{tabular}{|c|c|c|}
\hline Dimension & Basic targets & Benefits \\
\hline Economical & $\begin{array}{c}\text { - Increased } \\
\text { productivity, } \\
\text { - Greater security of } \\
\text { business, } \\
\text { - Consumers safety }\end{array}$ & $\begin{array}{c}\text { - Balance in the } \\
\text { environment, } \\
\text { - The good reputation of } \\
\text { the company, } \\
\text { - A higher level of } \\
\text { prosperity of nearest social } \\
\text { environment }\end{array}$ \\
\hline & $\begin{array}{c}\text { - Increase the level } \\
\text { of customer } \\
\text { satisfaction, } \\
\text { - Competitiveness } \\
\text { in relation to other } \\
\text { energy carriers, } \\
\text { - Strengthening of } \\
\text { the brand }\end{array}$ & $\begin{array}{c}\text { - An increase in demand } \\
\text { for products, }\end{array}$ \\
& $\begin{array}{c}\text { fecurity of supply of the } \\
\text { finished product }\end{array}$ \\
\hline
\end{tabular}

\begin{tabular}{|c|c|c|}
\hline Ecological & $\begin{array}{c}\text { - Reduction of } \\
\text { emissions, } \\
\text { - Do not exceed the } \\
\text { levels assigned } \\
\text { limits, } \\
\text { - The use of } \\
\text { environmentally } \\
\text { friendly production } \\
\text { technology and } \\
\text { residents }\end{array}$ & $\begin{array}{l}\text { - Less or no environmental } \\
\text { fines, } \\
\text { - A higher level of profit } \\
\text { achieved, } \\
\text { - Increase the value of the } \\
\text { company, } \\
\text { - The good reputation of } \\
\text { the company }\end{array}$ \\
\hline
\end{tabular}

It should be borne in mind, that the implementation of environmental and social aspects cannot be done without realizing the main objective of the enterprises operation which are profit maximization and increasing its value.

The sustainable management of the company consists seven steps [1]:

1. Carrying out the analysis of groups with common interests,

2. Determination of the principles and objectives of sustainable development,

3. Design and implementation of the agreed plan,

4. Develop an organizational culture supportive of sustainable development,

5. The development of measurement and standards activities,

6. Preparing reports,

7. Supporting internal monitoring system. 


\section{SUSTAINABLE DEVELOPMENT IMPLEMENTATION PHASES}

\subsection{Conducting the analysis of groups with common interests}

This analysis is necessary to identify all the groups, that are affected by the impact of the enterprise through actions taken by them. With this analysis, issues and information needs of all these groups are set out. The existence and activities of the company, is inseparably connected, not only with the global environment, but also the local community in which it operates. During the conduct of business, the company should maintain respect for human dignity and strive for a society, in which the environment is protected.

In the period from the beginning of the last century (until the 60s), companies are focused on maximizing profit, regardless of the excessive exploitation of raw materials or using the work of people, and do not care about the state of the nearest social environment, in a word, pursued a policy of "maximum development ". However, currently, companies operate in an environment more complex and have to deal with multiple regulations, whether it is legal or social. The law and regulations that cause actions coincide with the company's wider interest groups.

A sustainable development will extend the current interest groups for another - for future generations. Identification of interest groups centered around the company is not only a key element of sustainable development but also leads to greater social responsibility.

This analysis begins by identifying groups that are affected by the activities of the company. These groups consist of shareholders, lenders, regulators, employees, customers, suppliers and the whole social environment. These groups are also people, who in their own opinion is influenced by the company - whether through the environment or through social capital. After identifying each interest group, the company should consider any type of business and the place thereof. For some groups, the nature of the activities and location of the company may not be relevant, but for the other groups, and in particular local authorities, may make a difference. Therefore, the analysis should apply to determine the effects arising from the business enterprise and their impact on the natural environment, the local environment and future generations. To this end, the company should clearly formulate the needs and expectations of each of the identified groups. It should take into account, both current and future needs in order to implement the principles of sustainable development. The key here is to analyze the extent to which the business of an enterprise affects the interests of particular groups, both positively and negatively. The carried out result of the activities, have a dialogue with each of these groups. In order to establish it, company may create a so-called. advisory panel, composed by employees, shareholders and suppliers. Due to the fact, that the needs and expectations are constantly changing, they should be continuously monitored [2].

The conducted analysis may also reveal a conflict of interest. For example, enterprise customers expect new environmentally friendly products, and employees in connection with these requirements may fear for their jobs.

In turn, shareholders may be concerned about the amount of the expected profit. The analysis can be useful in identifying areas where there are conflicting interests and prevent them before they actually occurred.

\subsection{Determination of principles and objectives of sustainable development}

Another objective is to determine the fundamental values to which, as the company expects, its employees shall strive to implement sustainable development. Responsibility for the formulation of the principles of sustainable development for the company, falls on the person responsible for the overall management of the company. In addition to taking into account only the environmental aspect, it should be also taken into account the social and economic dimension. However, the creation of rules related with responsibility for the environment, is a good step towards the implementation of sustainable development for the company. A company, that has the right knowledge at the right time, and can be used to make optimal decisions, has the opportunity to achieve success through ahead of the competition and increase sales of their services or products [3]. The company should also take into account the expectations of stakeholders in the formulation of the company mission, taking into account the concept of sustainable development. Formulated mission will determine the value, under which all interest groups will identify. In addition to the formulation of the overall mission of the company, individual targets should be set, which will contribute to the achievement of sustainable development. It is important, that the objectives of sustainable development has been clearly formulated, have been achieved and expressed in measurable terms. After defining these objectives, the company should compare the adopted strategies (competitive and financial) to the objectives set, because in some areas, adopted strategies to some extent will implement formulated objectives of sustainable development, and in some areas they may cause a conflict. Then adopted strategy should be modified, because it is very important to the sustainability objectives to set out complementary strategies. In other words - sustainable development contributes to the creation of an extra dimension in the strategy. [4]

\subsection{Design and implementation of the agreed plan}

It is very important to design a plan, that change the current management system and will contribute to the achievement of sustainable development. The wording of the policy of sustainable development, so that it is understood in terms of business enterprise, will change throughout the enterprise. This entails a change in organizational culture, attitudes of employees, re-definition of responsibilities, causes changes in the organizational structure, information system, or in the same business. At the very beginning, after identifying and adopting sustainable development goals, all information should be communicated to particular groups, associated with the company. Some companies, even before the adoption of the plan, shall consult with certain groups, because they come from the assumption that, without prior consultation is not possible to develop an appropriate plan for all. The next step is to review the currently existing organizational structure, in order to identify individuals, who will be accountable for achieving the objectives of sustainable development. In some cases, this results in the creation of a special committee in the other - the creation of a special department. Some companies implement while the level of responsibility for each job, as proceed from the assumption that a clear definition of responsibility, is the key to the success of the adopted plan. 
Also planning process in an enterprise should be modified in such a way as to reflect the priorities of sustainable development, social consultations, and the need for external monitoring. Information management system should be amended to ensure the flow of information to employees, and managers. In turn, the company marketing activity should take account of the needs of customers, in the context of sustainable development. This in turn causes changes conducted by the marketing research company. The information obtained of these studies will help to change the design, manufacture, packaging, advertising and product promotion. In some cases, changed marketing research will allow for the discovery of new markets and adding them to the already existing ones.

In the meantime, the production process and procedures of the company must comply with the applicable regulations, common practices and internal standards in order to identify areas that need to be improved.

The existing regulations are easy to identify and implement, in spite of the fact that they are subjected to a continuous process of development. In contrast, the sustainability criteria are less precise, and so far they have not been clearly defined in the existing legal regulations.

At the same time, the person responsible for production processes need to review the suppliers, to ensure that the objectives of sustainable development are also implemented through procurement processes. In contrast, the financial plan of the company should determine the capital that is necessary to carry out the changes, account should also be taken tax or financial impact of implemented changes.

The success of the implemented plan based on changes in thinking across the enterprise, so that it can properly respond to the newly adopted priorities related to sustainable development. It is important here, not only to check the positive changes resulting from the adopted plan, but also the identification of barriers and sources of resistance. Despite the fact, that the main framework of activities of the company will remain the same, it will change the organizational culture and individual enterprise systems..

\subsection{Developing of organizational culture supporting principles of sustainable development}

Appropriate organizational culture is essential in order to ensure the full support of both, the company and its employees for sustainable development. In the implementation of sustainable development or environmental management, many companies experiencing a kind of rebirth of the company. Increased engaged employees not only results in practical solutions, but also causes an increase in support for the program itself. Both employees and customers are keen to be part of an organization, that operates in a socially responsible way. The implementation of sustainable development requires a change in the attitudes of managers themselves, which can only be achieved by carrying out appropriate training. Some managers, in turn, may have no awareness of the need for ecoefficient practices, others may not be aware that their actions can affect other groups, in addition to the company shareholders and others may refuse to change the method of evaluating their activities.

The importance of communication for the implementation of sustainable development is crucial. Inside the company, all managers and employees should fully understand the goals, that have been adopted for the implementation of sustainable development. One of the main objectives of the enterprise is to promote environmental awareness and social cross-section of the entire organization. This awareness should be taken into account in the daily communication as well as at all levels of decision-making.

Organizational culture is shaped not only by managers or directors, employees also have a large influence on its formation, as well as the impact of businesses on the environment. Because the concept of sustainable development requires the enterprise education as an organizational culture, in which all staff involved, will undergo a continuous process of learning and improvement.

Influence on organizational culture also have internal reporting systems. Their mission is to strengthen behave in accordance with the principles of sustainable development, should also be linked to the promotion of enterprise systems.

Also, active and visible involvement of senior management influences the formation of attitudes and creating an organizational culture oriented favorably for sustainable development. It is very important to assign appropriate responsibility for achieving the objectives of sustainable development and the creation of such a system of rewards and promotions, which will be able to recognize the people who take an active part in achieving the goals of sustainable development.

\subsection{Developing of measures and standards of activity}

Implementation of sustainable development and the development of reports, requires the creation of appropriate measures. Management controls as well as external reports depend on the availability of information on the activities of the company. This control is needed in order to allow management to assess the performance, using the appropriate procedures and measures.

The creation of metrics used to evaluate, will affect business objectives related to sustainable development, and standards set by governments or public agencies. For example, the evaluation results can affect emissions or energy consumption per tones of product produced for example, or the number of hours worked without any accident. The information obtained must have the appropriate measures to make it possible to compare the results against objectives. This leads sometimes to introduce new measures.

In many cases, enterprises, faster than governments introduce new measures or criteria by which you are measuring the occurrence of sustainable development. Due to the fact that the present society are more aware of the occurrence of environmental and social issues and put pressure to take appropriate action, you can expect greater involvement of governments in the future.

Establishing and developing new measures and standards is a very good opportunity to establish cooperation between enterprises and the government of the country. This cooperation can lead to the development of the system of reporting, and monitoring, which will not only cost effective, but will meet the requirements of both the companies and governments.

\subsection{Preparing reports}

The next step is to develop internal reports for managers and owners, in which will be included guidelines for sustainable 
development, and comparison of company performance against objectives. Managers use these reports to evaluate the activities, decision-making and monitoring the implementation of the adopted strategy or policy. The owners, lenders, employees and customers benefit from external reports to assess the activities of the company, and accounting management of performance-related targets adopted financial, social and environmental.

Despite the fact that financial reports are still a major component of the reporting system in the enterprise, now, next to them, there are many types of reports, periodically published [5].

It is very important to reduce the differences between the reports that measure economic activity and enterprise reports, which contain data on the use of natural resources by the company. For example, financial reports do not reflect the degree of utilization of natural resources, as a result of these reports presented by the company, it fails to adopt any measures related to environmental protection, will present lower costs and larger revenues than the company actively pursuing environmental policy. This system requires appropriate incentives and relevant information that will positive behavior that the organization will be rewarded. For, companies that pollute the air, soil or water, or otherwise adversely affect the environment, have a high income part of which goes to the state budget. Therefore, it becomes important to develop a clear and transparent system of reporting. System that will provide a complete picture of company performance related to sustainable development, which will enhance its credibility and allow for effective contact with groups that remain under the influence of its activities.

Inside the company, should be introduced procedure requiring managers to introduce them to create the report, a statement whether they achieved their targets on the implementation of sustainable development. Also, top management should periodically receive reports of which will be apparent whether or not the objectives have been achieved.

However, every company or organization at least once a year, should publish so called sustainability report. As it has not yet been developed a standard format for this type of report, each company should develop its own format.

\subsection{Supporting of internal monitoring system}

It is very important to develop appropriate mechanisms to ensure the implementation of sustainable development policies in the enterprise. A properly designed monitoring process is an important element in the management process. In many areas it is directly connected to the reporting system. The key to the success of this system, is that if the process is controlled on a regular basis. By contrast, in Poland, in the light of the adopted laws and regulations, can formulate the following obligations for traders in the use of the environment [6]:

- obligation to rational management of the environment,

- obligation to prevent negative effects on the environment,

- obligation to use technologies, that meet the requirements of environmental protection and to ensure the environmental safety of products,

- the obligation to obtain required permits and compliance with established standards using the environment,

- obligation to keep the measurements and make available information on pollution,
- the obligation to compensate for damage to the environment arising with the use of the environment,

- to establish on-demand security authority claims for damages that may arise in the environment,

- to draw up a report on the impact of projects on the environment,

- the obligation to submit to the request of the competent administrative authority ecological survey,

- the obligation to pay fees for the use of the environment.

- a little bit different looks the case in the energy sector, in which sustainable development is characterized by [7]:

- $\quad$ power users can take full advantage of its basic functions while maintaining a minimum level of its negative impact on the environment,

- development of an energy company, with taking his responsibility for pollution or consume natural resources,

- increase the use of raw materials from renewable energy sources instead of conventional raw materials,

- maintenance of biological diversity with the development of modern technology,

- adapting the methods and goals of the company action level and the development of technical knowledge,

- access to environmental information,

For the above principles, it is possible to construct a strategy for balancing economic development of the society, together with the quality of the environment, when the following criteria are met: [8]

- $\quad$ shift towards lifestyle consisting of the union of man with the environment,

- diversity of society,

- guarantee the integrity of areas characterized by unique values and which are classified as natural heritage

- striving for regional development in accordance with the tradition, culture and local conditions,

- harmonious development in all areas: environmental, social, technical and spatial

- $\quad$ use in manufacturing processes so clean technology and preference for products, which do not harm the environment,

- shaping the strategy for the protection of health in accordance with the guidelines of the World Health Organization,

- $\quad$ protection of cultural goods, both material and immaterial, which is a national heritage,

- decision-making in a democratic manner, taking into account the effects they may bring in the future.

\section{CONCLUSIONS}

In summary, the definition of sustainable development is usually a set of rules for which compliance, will ensure the continued development of future generations to respect the environment. It should be emphasized that the concept of sustainable development focuses not only on the present generation, but puts a strong emphasis on future generations and their unidentified needs. This observation refers to the concept of J. Elkington who said, that the success of the company consists of just these three components. He was also the first person to propose the parallel their consideration and balancing - the so-called. Triple Bottom Line. In this perspective, the concept of sustainable development, from the point of view of enterprises, it is not only action to protect the environment by, for example reducing the level of emissions and ensure an appropriate level of security for their employees, 
but the concept is the foundation for the intelligent management of the company.

\section{REFERENCES}

1. Business strategy for Sustainable Development: Leadership and Accountability for the 90s, IISD, WBCSD 1992.

2. Nowak S., Franczak A.; Zarządzanie konkurencyjnością a CSR i zrównoważony rozwój przedsiębiorstwa, Logistyka. - 2012, nr 6, pp. 190-196

3. Nycz M., „Business intelligence technologią dostarczającą Informacji i wiedzy menedżerskiej", w: Korczak J., Chomiak-Orsy I., Sroka H. (red.): Systemy informacyjne w zarządzaniu, Wyd. UE we Wrocławiu, Wrocław 2010, p. 3.

4. Tabor J.: Behaviors of Small- and Medium-Sized Enterprises in the Face of Employee Entrepreneurship, [in:] Determinants of Entrepreneurship Development in SME Sector Companies. Monograph. Ed. Stefan
Lachiewicz, Katarzyna Szymańska, Magdalena Kurowska, Wyd. Techn. Univ. Lodz. Press, Łódź 2011, pp.292-311.

5. Brzeziński S., „Podstawowe uwarunkowania rozwoju przedsiębiorczości”, w: „Determinanty zarządzania i rozwoju przedsiębiorstw", red. Otola I, SkowronGrabowska B., Wydział Zarządzania, Politechnika Częstochowska, Częstochowa 2006, p. 168.

6. Kot S., Ślusarczyk B., Sustainable Development Analysis in Transport Process, Studia Ekonomiczne Zeszyty Naukowe Wydziałowe Uniwersytetu Ekonomicznego w Katowicach nr 121/2012, pp. 141-146

7. Brzozowska A., Selected Problems of Strategic Management of Enterprises, Technical University of Ostrava, 2013, pp. 7-15

8. Stochlak J.M., Podolak M., „Ochrona środowiska w Polsce. Studium prawno-politologiczne", Uniwersytet Marii Curie-Skłodowskiej, Lublin 2006, p. 81-82. 